\title{
THE NECESSITY AND IMPORTANCE OF THEOLOGICAL ENGAGEMENT WITH NON- MUSLIMS FOR SINGAPORE MUSLIM COMMUNITY
}

\author{
Muhammad Haniff Bin Hassan*
}

\begin{abstract}
This paper argues the importance and necessity for Singapore Muslims to be actively involved in theological engagement with non-Muslims in the form of dialogue on theological, social and historical grounds. Theologically, the paper argues that Islam not only permits but also encourages Muslims to engage in dialogue with non-Muslims on theological issues. At a societal level, being a Muslim minority in a secular country and multi-cultural society, the preservation and pursuance of their interest would partly rely on how they relate with and how they are perceived by the larger diverse non-Muslim communities. It is in their interest to actively engage and have dialogue with other communities. Historically and more importantly, Muslim involvement in inter-faith dialogue preserves the legacy left behind by Maulana Abdul Aleem Siddique who pioneered the inter-faith work in Singapore through the founding of the Singapore Inter-Religious Organisation. The paper also refutes those who oppose interfaith dialogue theologically and those who discourage Muslim involvement for fear of falling into the government's political agenda. The primary research methodology employed by the paper is through literature review of primary and secondary materials. It also employs interviews of local activists and professionals in inter-faith work as a secondary methodology.
\end{abstract}

Keywords: Inter-Faith Dialogue, Muslim and Non-Muslim Relations, Singapore Muslims, Maulana Abdul Aleem Siddique, Inter Religious Organisation of Singapore (IRO)

\section{Introduction}

Singapore is reported to be the most religiously diverse country by Pew Research Center. ${ }^{1}$ Unlike many multi-religious countries, various religious communities and ethics have been living together in peace and harmony for decades. This has won the country much praise from all over the world. However, the above-mentioned condition did not come by easily. It was achieved through dedication and hard work on the part of the government alongside both community and religious leaders; after bitter experiences from racial and religious riots in late 1950s and '60s. Thus, racial and religious harmony is guarded with much jealousy by the government. Various laws and initiatives are put in place in order to continuously protect and promote peaceful coexistence between people of various faiths in the country since the country's independence in $1965 .^{2}$

One of the key areas used for the advancement of peace and harmony between people of different faiths is the inter-faith dialogue, where leaders of different faiths come together to share religious knowledge for the purpose of promoting understanding, dispelling misconceptions and prejudices between them. In addition to constructive theological exchanges, activities that bring together followers of different faiths in the form of social and humanitarian initiatives are also organised in order to strengthen the bond, trust and confidence that would be critical should a crisis like terror attacks perpetrated by followers of a faith against others were to occur.

Although inter-faith dialogues initiatives have been around in Singapore even during the British colonial rule, it has been given more importance after the September 11 attacks by Al-Qaeda and the subsequent discovery of attack plots in Singapore by Singaporean members of Jemaah Islamiyah - an Al-Qaeda affiliated organisation based in Indonesia. Interfaith dialogue is thus a response to the divisive

\footnotetext{
* Muhammad Haniff Bin Hassan, Fellow, S. Rajaratnam School of International Studies, Nanyang Technological University, Singapore. Email: ismhaniff@ntu.edu.sg.

${ }^{1}$ Pew Research Center (2014), Global Religious Diversity, retrieved 19 ${ }^{\text {th }}$ Sptember 2019, https://www.pewforum.org/2014/04/04/globalreligious-diversity/.

${ }^{2}$ See Lai Ah Heng (ed.) (2008), Religious Diversity in Singapore, Singapore: ISEAS; Mackenzie Perkins (2019), "Singapore: The Most Religiously Diverse Country in the World," Learn Religions, retrieved $19^{\text {th }}$ September 2019, https://www.learnreligions.com/singaporereligion-4766642.
} 
ideology held by the groups that seek to create a wedge between Muslims and non-Muslims by fueling religious conflicts so that they can capitalise on the subsequent divisions for their political gains.

This paper seeks to argue that inter-faith dialogue is a religious, social and traditional necessity for the Singapore Muslim community. This paper seeks to achieve two objectives; 1) to increase awareness among members of the community on the importance of Muslim's participation in inter-faith dialogue in Singapore's context in the hope that more would come forward to deepen their understanding of their faith and of others and in doing so, the foundations of Singapore's religious harmony can thus continue into the next generation, and, 2) to address two specific ideological camps that forbids Muslims from participating actively within inter-faith dialogues.

There are two camps among Muslims that forbid fellow Muslims from participating and contributing in inter-faith dialogue, engagement and similar events.

\section{Jihadist/Extremist Camp}

The first camp subscribes to the extremist ideology of groups such as the Islamic State (IS), the Indonesian Jemaah Islamiyah (JI) and Al-Qaeda known commonly as jihadism. These groups are regarded by the Singapore Government as one of primary threats to the country's national security and social harmony. This ideology has motivated many youths in various countries to commit acts of terrorism and Singapore has not been spared from this trend - as indicated from reported cases under the Internal Security Act with the numerous arrests of Singaporean JI (Jemaah Islamiyah) members till date. ${ }^{3}$ This camp denounces inter-faith dialogue as an exercise in futility, a waste of resources, and a distraction from obligatory jihad.

The camp argues that armed jihad against infidel non-Muslims is the most important religious obligation for contemporary Muslims in view of the absence of a legitimate Islamic state or a caliphate. They view other Muslim countries as apostate governments or proxies for infidels; often referring to Iraq, Afghanistan and Palestine as occupied Muslim lands. ${ }^{4}$ In their view, the conditions in these lands has resulted in prolonged abandonment of the shari ah from Muslim life - which they correlate to the fundamental cause for the current sorry state of affairs for all Muslims the world over. ${ }^{5}$ Given the state of Muslim lands today, this camp believes that armed jihad has become a fard ain (individual obligation) of every Muslim and should take precedence over all peaceful da wah (Islamic propagation). ${ }^{6}$

This camp also denounces inter-faith dialogue on the basis of Al-Wala' Wa Al-Bara' (AB). AB is regarded as a pillar of Islamic creed ('Aqidah) by the proponents of jihadism. It is a concept that determines and differentiates to whom Muslims should and should not give their loyalty, obedience and love based on Qura'nic verses such as 3:28, 5:51, 9:71, 9:23, 58:22; 60:1-4. According to the followers of this camp, the Qur'an commands Muslims to practice al-wala' (loyalty, obedience, allegiance, brotherhood and loyalty) to fellow Muslims only and al-bara' (the opposite meaning of al-wala') to infidels. $^{7}$

Those in this camp believe infidels should be regarded, in principle, as hostile enemies because of their inherent characters mentioned in the Qur'an; they will never be pleased with Muslims (the Qur'an, 2:120) and would constantly conspire among themselves to make Muslims abandon the true Islamic way of life (the Qur'an, 2:217). Their understanding of $\mathrm{AB}$ makes them regard inter-faith dialogue as fraternising with enemies that contradicts the principle of al-bara' towards all infidels/non-Muslims. ${ }^{8}$ IS (The Islamic State group) articulates the above view clearly in its online magazine Dabiq. ${ }^{9}$

\footnotetext{
${ }^{3}$ See Ministry of Home Affairs (2003), White Paper; Jemaah Islamiyah and the Threat of Terrorism, Singapore: Ministry of Home Affairs. ${ }^{4}$ See Muhammad Haniff Hassan (2009), "Jihadi Ideology: An Overview," in Arnaud de Bochgrave, Thomas Sanderson and David Gordon (eds.), Conflict, Community and Criminality in Southeast Asia and Australia, CSIS, Washington, pp. 76-83.

${ }^{5}$ Muhammad Haniff Hassan (2009), “Jihadi Ideology: An Overview," pp. 76-83.

${ }^{6}$ Muhammad Haniff Hassan (2009), "Jihadi Ideology: An Overview," pp. 76-83.

${ }^{7}$ Muhammad Haniff Hassan (2009), “Jihadi Ideology: An Overview,” pp. 76-83; See Mohamed Ali (2015), Roots of Religious Extremism:

The Understanding the Salafi Doctrine of Al-Wala' Wal Bara', London: Imperial College Press.

${ }^{8}$ Mohamed Ali (2015), Roots of Religious Extremism.

${ }^{9}$ Mohamed Ali (2015), Roots of Religious Extremism; Dabiq, no. 15, p. 76; Dabiq, no. 14, pp. 31-33.
} 


\section{Conservative Muslim Camp}

The second camp opposing inter-faith dialogues belong to those who subscribe to the conservative ideology among some Muslim towards inter-faith understanding. Some of the proponents of this camp share the abovementioned $\mathrm{AB}$ concept from which they build upon their negative attitude towards interfaith understanding. Similar to the above jihadist/extremist camp, they hold that the relationship between Muslims and infidels will always be enmity, not brotherhood. This enmity is manifested in the form of injustices and destruction imposed by infidels upon Muslims in many Muslim countries. This contradicts inter-faith dialogue's key objectives which are to promote tolerance, amity and brotherhood with people of other faiths. Muslims' participation in inter-faith dialogue would not do justice to the sufferings of Muslims in the hand of the infidels. ${ }^{10}$

Some prohibit inter-faith dialogue due to their rejection of religious perennialism - a religious philosophy that views all religions to share a single metaphysical truth, each represents different path that will eventually lead to the same truth, each is equally valid and no religion should claim superior than others or it is the only truth - that is perceived to have dominated inter-faith dialogue field. Interfaith dialogue is seen by this camp as the means to promote perennialism. In their view, religious perennialism is incompatible with Islam because they believe that Islam is the only religion recognised by God and remains the only way to salvation in Afterlife. This, to them, has been clearly stated in the Qur'an (3:19, 83 and 85) and a consensus of Muslim scholars. Since there is only one religion, the idea of dialogue or bridging (taqrib) between religions or faiths is anathema to Islam. Muslims should be prohibited from participating in inter-faith dialogue activities because it poses serious risk to the Muslim faith and is tantamount to recognition of other faith as a religion. ${ }^{11}$ The proponents argue there is no benefit in having dialogue with non-Muslims whose sole intention is to bring Muslims to follow their false faiths and away from truth as warned by the Qur'an in 2:120. ${ }^{12}$

\section{Detractors in Singapore}

There is currently no comprehensive study on Singaporean Muslims' attitudes towards inter-faith dialogue to ascertain the level of rejection towards it. Additionally, there are no documents that that can be referred to understand the above arguments in detail. However, activists, academics and professionals in the field of Singapore's inter-faith dialogue, through interview, admit their encounter with the above two viewpoints, albeit an uncommon one. As such, they agreed that the views could be held only by small minority of Singaporean Muslims. ${ }^{13}$

\footnotetext{
${ }^{10}$ Interview with professionals and activists in inter-faith dialogue in Singapore in note 13; Qanat Al-Shaykh Khalid Al-Faluji (2019), Rad AlAllamah Al-Fawzan 'Ala Du'at Al-Tasamuh Wa Wahdat Al-Adyan, retrieved 27 ${ }^{\text {th }}$ July 2020, https://www.youtube.com/watch?v=nVmcel8yvhI; 'Abd Al-Rahim Samayil Al-Silmi (n.d.), Al-Hiwar Bayn Al-Adyan: Haqiqatuh Wa Anwa 'uh, n.pl.: n.p., pp. 19, 22, 24-25; Manarat Al-Tariq (2019), Aqwa Rad Min Al-Turaifi Li Du 'at Hiwar Al-Adyan Wa Al-Ta `ayush Wa AlTasamuh, retrieved $27^{\text {th }}$ July 2020, https://www.youtube.com/watch?v=vz_A9Q2ArYE; Ghadah Zuhayr (2018), "Ghita' Siyasi Li Mumarasat Al-Bash 'ah!", Aljazeera blog, retrieved 27 July 2020, https://www.aljazeera.net/blogs/2018/9/20/\%D8\%AD\%D9\%88\%D8\%A7\%D8\%B1$\%$ D8\%A7\%D9\%84\%D8\%A3\%D8\%AF\%D9\%8A\%D8\%A7\%D \% $\% 86-\%$ D8\%BA\%D8\%B7\%D8\%A7\%D8\%A1-

\%D8\%B3\%D9\%8A\%D8\%A7\%D8\%B3\%D9\%8A-\%D9\%84\%D9\%85\%D9\%85\%D8\%A7\%D8\%B1\%D8\%B3\%D8\%A7\%D8\%AA$\% \mathrm{D} 8 \% \mathrm{~A} 8 \% \mathrm{D} 8 \% \mathrm{~B} 4 \% \mathrm{D} 8 \% \mathrm{~B} 9 \% \mathrm{D} 8 \% \mathrm{~A} 9$.

${ }^{11}$ Al-Faluji (2019), Rad Al- 'Allamah Al-Fawzan 'Ala Du 'at Al-Tasamuh Wa Wahdat Al-Adyan; Md. Sanaullah (2014), "Interfaith Dialogue in Islam: A Scriptural Scrutiny," Journal of Humanities and Social Sciences, Vol. 19, No. 3, pp. 86-91; Al-Islam Su'al Wa Jawab (2000), Hukm Al-Da wah Ila Taqarub Al-Adyan, retrieved $19^{\text {th }}$ September 2019,

https://islamqa.info/ar/answers/10232/\%D8\%AD\%D9\%83\%D9\%85-\%D8\%A7\%D9\%84\%D8\%AF\%D8\%B9\%D9\%88\%D8\%A9-

$\% \mathrm{D} 8 \% \mathrm{~A} 7 \% \mathrm{D} 9 \% 84 \% \mathrm{D} 9 \% 89-\% \mathrm{D} 8 \% \mathrm{AA} \% \mathrm{D} 9 \% 82 \% \mathrm{D} 8 \% \mathrm{~A} 7 \% \mathrm{D} 8 \% \mathrm{~B} 1 \% \mathrm{D} 8 \% \mathrm{~A} 8$ -

\%D8\%A7\%D9\%84\%D8\%A7\%D8\%AF\%D9\%8A\%D8\%A7\%D9\%86; Al-Kitab Wa Al-Sunnah Bi Fahm Salf Al-Ummah (2015), Hukm Hiwar Bayn Al-Adyan (Salih Al-Fawzan), retrieved 27 July 2020, https://www.youtube.com/watch?v=vMCRdnB491Y; Suha Abas (2019), Mafhum Hiwar $\quad$ Al-Adyan, $\quad$ retrieved $\quad 19^{\text {th }} \quad$ September https://hyatoky.com/\%D9\%85\%D9\%81\%D9\%87\%D9\%88\%D9\%85_\%D8\%AD \%D9\%88\%D8\%A7\%D8\%B1_\%D8\%A7\%D9\%84\%D8\% A7\%D8\%AF\%D9\%8A\%D8\%A7\%D9\%86; 'Abd Al-Rahman Nasir Al-Barrak (n.d.), Al-Da wah Ila Wahdah Al-Adyan Min Nawaqid AlIslam, retrieved $19^{\text {th }}$ September 2019, https://www.saaid.net/fatwa/f64.htm; AshashaS (2016), Al-Shaykh Ibn 'Uthaimin Yuljim Du 'at Tawhid Al-Adyan, retrieved $27^{\text {th }}$ July 2020, https://www.youtube.com/watch?v=jMoYf97UwMs.

${ }^{12}$ Al-Kitab Wa Al-Sunnah Bi Fahm Salf Al-Ummah (2015), Online.

${ }^{13}$ The interview involves 10 individuals who are either professional or activist in inter-faith work ( 1 university lecturer in inter-faith field, 2 former senior executives of inter-faith organisation, 1 current head of inter-faith NGO, 1 senior executives of an inter-faith organisation, 1 junior executive of an inter-faith organisation, 1 executive imam and activist of inter-faith work, 2 chairpersons of mosque management board and 1 activist of inter-faith work). Each are required to answer four open-ended questions; 1) Have you come across negative comments/condemnations/rejections/ towards inter-faith dialogue initiatives? 2) What are the arguments given for such expressions? 2) How do you come across them? (in person, writing, online, offline), 4) Do you know of any source that contains such comments i.e books, websites, articles, Facebook groups, chats?; And two rating questions; 1) How often do you come across them? in the scale of 1 [not often] to 5 [very often]), 2) How prevalent do you think such attitude exist among Muslims in Singapore? in the scale of 1 [not prevalent] to 5 [very prevalent].
} 
The closest studies currently available about Singapore Muslims' negative attitudes towards inter-faith dialogue pertain to the condition of religious harmony and the level of religiosity in Singapore. They contain data from which attitudes towards inter-religious relations could be deduced.

A study reports that less than 20 percent of Muslims were not comfortable when it comes to relationships with people of other faiths in the public sphere. While inter-faith dialogue is not clearly stated as a variable used to gauge, it could suggest as an indicative of the Muslim respondents' attitude towards public engagement with other faiths. ${ }^{14}$ This figure corresponds with experiences shared in the abovementioned interview.

Despite the fact that Muslims who hold negative views towards inter-faith dialogue in Singapore are a small minority, this should not lessen the value of this paper in articulating the necessity of inter-faith dialogue for Muslims in Singapore. Firstly, clear articulation of argument is not only beneficial for the purpose of refuting detractors or correcting negative attitudes. The argument is also necessary for existing and potential activists so they could contribute to the field with stronger conviction.

Secondly, the case of JI ideology is a reminder to not take for granted the serious consequences of minority-held ideology, especially when it relates to what is regarded as important pillar of Singapore society i.e. preservation and promotion of social and religious harmony. JI ideology is not exclusive to the group. It is the same ideology propagated by Al-Qaeda and IS to Muslims in general. Although the ability of both groups to launch terrorism attacks has diminished significantly due to battlefield losses, the ideological threat remains serious in many countries from the reported arrests and attacks by individuals influenced by this dangerous ideology that is easily accessible and communicated through online platforms.

Thirdly, Singaporean Muslims are not immune from the abovementioned challenge, even after two major arrests of JI members in 2001 and 2002. Since then, arrests of self-radicalised individuals were reported annually. Till 2019, about 27 Singapore citizens radicalised through online platforms were arrested under the Internal Security Act. About 40 others from Bangladesh, Indonesians and Malaysian were dealt too under the same Act. ${ }^{15}$

With regard to negative attitudes towards peaceful and positive interaction with non-Muslims, the challenge is greater because such understanding is also subscribed by conservative Muslims who represent a larger pool than the violent extremists. The following section of this paper highlights the importance and necessity of Muslim contribution to inter-fait dialogue.

For the purposes of discussion, inter-faith dialogue is understood as follows:

It is about people of different faiths coming to a mutual understanding and respect that allows them to live and cooperate with each other in spite of their differences. The term refers to cooperative and positive interaction between people of different religious traditions, (i.e. "faiths") at both the individual and institutional level. Each party remains true to their own beliefs while respecting the right of the other to practise their faith freely. Interfaith dialogue is not just words or talk. It includes human interaction and relationships. It can take place between individuals and communities and on many levels. For example, between neighbours, in schools and in our places of work - it can take place in both formal and informal settings. ${ }^{16}$

This definition is chosen because it stipulates clearly that the objective of inter-faith dialogue is to promote mutual understanding, respect, positive interaction between communities, devoid from the need to compromise one's religious principles and to recognise that all religions are equally valid. These are elements that would make inter-faith dialogue compatible to Islamic teachings in the next section.

\footnotetext{
${ }^{14}$ Mathew Mathews, Mohammad Khamsya bin Khidzer and Teo Kay Key (2014), "Religosity and the Management of Religious Harmony: Responses From IPS Survey on Race, Religion and Language,” IPS Working Paper, No. 21, pp. 52-53.

${ }^{15}$ See Ministry Home Affairs, Press Releases 2007-2019, retrieved 28 ${ }^{\text {th }}$ July 2020, https://www.mha.gov.sg/newsroom/press-release.

${ }^{16}$ Gerard Forde (2013), Journey Together: A Resource for Christian Muslim Dialogue, Ireland: Cois Tine, p. 7, retrieved 19 ${ }^{\text {th }}$ September 2019, https://www.dublincityinterfaithforum.org/cmsfiles/resources/a-journey-together.pdf.
} 


\section{Responding to Detractors, Establishing Theological Bases}

It is not the objective of this paper to address every issue raised by the detractors. Due to space constraints, this paper will only focus on key arguments.

Three ideas could identified being the main arguments that inter-faith dialogue is a compromise of Islamic faith and a dilution of Muslim's $d a$ 'wah commitment in calling mankind to embrace Islam; a) the question of legitimacy of inter-faith dialogue in Islam, b) the opinion that inter-faith dialogue contradicts the main purpose of Islamic $d a$ 'wah, and c) the view that inter-faith dialogue is a deception crafted by non-Muslims to deviate Muslims from the true Islam. ${ }^{17}$

On the question of legitimacy of inter-faith dialogue in Islam, it is argued here that there are various verses in the Qur' an that permissibility of inter-faith dialogue and Islam's encouragement of it could be deduced. ${ }^{18}$ Some of these verses speak directly to a category of non-Muslims known as the People of the Book. Some verses call upon Muslims to engage in dialogue with the People of the Book i.e. the Qur'an, 3:64, 4:171, 16:125 29:46 and 10:94.

Although the Qur'an in 16:125 and 29:46 uses the word "jidal" which usually means "debate" or "argue" when encouraging Muslims to engage with non-Muslims, it does not connote adversarial debate or argument often seen in political arena that leads to tension and strain between parties involved.

The Qur'an predicated the word "jidal" with the phrase "in a most kindly manner". A more accurate understanding of "jidal" is to have dialogue and conversation. This is in line with another verse in the Qur'an that commands Muslims to build common ground when interacting with non-Muslims as mentioned in 3:64. This is the position of Sheikh Al-Qaradawi when he discusses the permissible and impermissible in inter-faith dialogue in his book on Muslim minorities living in non-Muslim countries. ${ }^{19}$ This is in line with the position of most classical and contemporary tafsir scholars who are inclined to interpret "in a most kindly manner" with words such as gentle, lenient, courteous and polite, in contrast of harsh, coarse, vulgar and rude. ${ }^{20}$ Some scholars relates the meaning of the phrase with the verse that command Prophet Moses and Aaron to speak "in a mild manner (qawlan layyinan)" (The Qur'an, 20:44) when preaching to Pharaoh as an example. ${ }^{21}$

From a linguistic perspective, it can be highlighted that the verb in, "and argue with them (wa jadilhum)" (The Qur'an: 16:25) is expressed in fi il al-amr (command verb), which connotes a strong encouragement for the purpose of sharing the message of Islam to humanity at large, when it is combined with relevant verses in 3:64, 4:171, 29:46 and 49:13. ${ }^{22}$

\footnotetext{
17 `Abd Al-Rahim Samayil Al-Silmi (n.d.), Al-Hiwar Bayn Al-Adyan, pp. 3, 18-21; Muhammad Husain `Abd Allah (2016), "Mawqif Al-Islam Min Al-Hiwar Bayn Al-Adyan," Majallat Al-Wa iy, retrieved 19 ${ }^{\text {th }}$ September 2019, https://www.al-waie.org/archives/article/3700; Jawad Bisyarah (2002), "Haqiqat Al-Hiwar Bayn Al-Adyan," Al-Hiwar Al-Mutamaddin, retrieved 19 http://www.ahewar.org/debat/show.art.asp?aid=2784\&r=0; Abd Al-Rahman Nasir Al-Barrak (n.d.), Al-Da 'wah Ila Wahdah Al-Adyan Min Nawaqid Al-Islam, Online; Anis Malik Taha (2010), "Hiwar Al-Adyan Bayn Bina' Jusur Al-Tafahum Wa Hifz Al-Hawiyah," Al-Tajdid, Vol. 14, No. 27, pp. 143-146; Md. Sanaullah (2014), "Interfaith Dialogue in Islam,” pp. 86-91.

${ }^{18}$ See Ahmet Kurucan and Mustafa Kasim Erol (2012), Dialogue in Islam: Quran - Sunnah - History, London: Dialogue Society; Mohammad Sa id Mitwally Ibrahim (2010), "Inter-Faith Dialogue: A Muslim Legal Perspective on Its Validity, Concept and Practices," INSIGHTS: Muslim-Non-Muslim Relations, Vol. 3, No. 1, pp. 93-126; Ingrid Matson (2013), Of Fences and Neighbors, pp. 1-16, retrieved 19 ${ }^{\text {th }}$ September 2019, http://ingridmattson.org/article/of-fences-and-neighbors/.

${ }^{19}$ Yusuf Al-Qaradawi (2001), Fi Fiqh Al-Aqalliyat Al-Muslimah, Qahirah: Dal Al-Shuruq, pp. 67-68.

20 Except otherwise mentioned, all tafsir books in this article are based on online tafsir library at https://www.altafsir.com/Tafasir.asp?tMadhNo $=0 \& \mathrm{tTafsirNo}=0 \& \mathrm{tSoraNo}=1 \& \mathrm{tAyahNo}=1 \& \mathrm{tDisplay}=$ no \&LanguageID $=1 \quad\left(\mathrm{retrieved} \quad 16^{\text {th }}\right.$ June 2020). See Al-Tabari, Jami 'Al-Bayan Fi Tafsir Al-Qur'an, in 16:125 and ; Ibn Kathir, Tafsir Al-Qur'an Al-Azim, in 16:125 and 29:46; Al-Baidhawi, Anwar Al-Tanzil Wa Asrar Al-Ta'wil, in 16:125 and 29:46; Ibn Al-Jawzi, Zad Al-Masir Fi 'Ilm Al-Tafsir, in 16:125; Al-Nasafi, Madarik Al-Tazil Wa Haqaiq Al-Ta'wil, in 16:125 and 29:46; Al-Khazin, Lubab Al-Ta'wil Fi Ma 'ani Al-Tanzil, in 16:125; Al-Jazairi, Aysar Al-Tafasir Li Kalam Al- 'Aliy Al-Kabir, in 16:125; Al-Alusi, Ruh Al-Ma 'ani, in 16:125 and 29:46; Al-Sha 'rawi, Khawatir, in 16:12 and 29:46; Tantawi, Al-Wasit Fi Tafsir Al-Qur'an Al-Karim, in 16:125; Al-Qurtubi, Al-Jami 'Li Ahkam Al-Quran, in 29:46; Al-Shawkani, Fath Al-Qadir, in 29:46; Ibn 'Ashur, Al-Tahrir Wa Al-Tanwir, 29:46; Al-Shinqiti, Adhwa'Al-Bayan Fi Tafsir Al-Qur'an, in 16:125

${ }^{21}$ See Al-Tabari, Jami 'Al-Bayan Fi Tafsir Al-Qur'an, in 16:125 and ; Ibn Kathir, Tafsir Al-Qur'an Al-Azim, in 16:125 and 29:46; Al-Baidhawi, Anwar Al-Tanzil Wa Asrar Al-Ta'wil, in 16:125 and 29:46; Ibn Al-Jawzi, Zad Al-Masir Fi 'Ilm Al-Tafsir, in 16:125; Al-Nasafi, Madarik AlTazil Wa Haqaiq Al-Ta'wil, in 16:125 and 29:46; Al-Khazin, Lubab Al-Ta'wil Fi Ma 'ani Al-Tanzil, in 16:125; Al-Jazairi, Aysar Al-Tafasir Li Kalam Al- Aliy Al-Kabir, in 16:125; Al-Alusi, Ruh Al-Ma 'ani, in 16:125 and 29:46; Al-Sha rawi, Khawatir, in 16:12 and 29:46; Tantawi, AlWasit Fi Tafsir Al-Qur'an Al-Karim, in 16:125; Al-Qurtubi, Al-Jami 'Li Ahkam Al-Quran, in 29:46; Al-Shawkani, Fath Al-Qadir, in 29:46; Ibn 'Ashur, Al-Tahrir Wa Al-Tanwir, 29:46; Al-Shinqiti, Adhwa' Al-Bayan Fi Tafsir Al-Qur'an, in 16:125.

22 Islamweb (2010), Sighat (Al-Amr) Fi Al-Qur'an, retrieved $16^{\text {th }}$ June 2020 , https://www.islamweb.net/ar/article/150641/\%D8\%B5\%D9\%8A\%D8\%BA\%D8\%A9-\%D8\%A7\%D9\%84\%D8\%A3\%D9\%85\%D8\%B1$\%$ D9\%81\%D9\%8A-\%D8\%A7\%D9\%84\%D9\%82\%D8\%B1\%D8\%A2\%D9\%86; 'Ali Jum`ah Muhammad (2017), "Dilalat Sighatay Al-Amr Wa Al-Nahy," Dar Al-Ifta'Al-Misriyah, retrieved $16^{\text {th }}$ June 2020, http://www.fatawa.com/view/15323.
} 
It could also be argued that dialogue is the implied command of God when He states that Man is purposefully created with a diverse range of ethnicities, cultures, linguistics etc. so they will get to know and learn from each other (the Qur'an, 49:13). If the divine purpose of this creation is positive, the right means to it must be positive too and that is peaceful dialogue and interaction for mutual understanding, not war or adversarial debate. ${ }^{23}$ If the Qur'anic verses that encourage dialogue with non-Muslims are connected with Qur'anic verses that commands Muslim to perform da 'wah (propagation of Islam), it could be concluded that dialogue with non-Muslims is one of many recommended methods of $d a{ }^{~}$ wah that Muslims must utilise. ${ }^{24}$

There are many hadiths (the Prophet's reported traditions) and historical reports highlighting the Prophet's engagement in dialogue with non-Muslims on theological matters. One of the most popular examples is the Prophet's dialogue with a Christian priest from Najran (located in Yemen). The dialogue ended with the Christian priest returning to Najran without converting to Islam. ${ }^{25}$

Permissibility of inter-faith dialogue could also be argued on the grounds that Islam calls upon Muslims to seek cooperation with anyone for the purpose of promoting virtues and preventing evils as stipulated in The Qur'an, 5:2 and exemplified by the Prophets such as his participation in Hilf Al-Fudhul (AlFudul Confederacy) and Harb Al-Fijar (Sacrilegious war). ${ }^{26}$ Examples of the common ground issues are promoting morals, speaking for the oppressed and countering extremism. ${ }^{27}$

The second argument emerges from the view that Islam is a religion for all Mankind, not to a specific ethnic group i.e. Arab or Malay, or locality i.e. Middle East or Nusantara as clearly understood from the Qur'an in 7:158, 34:28 and 21:107. To achieve this, da 'wah is commanded upon all Muslims in order to bring those who are not in its fold to embrace the religion. This follows the footsteps of past Muslims such as those who transformed this region from a predominantly Hindu-Buddhist to predominantly Muslims.

Detractors object to inter-faith dialogue because the accepted rule among the participants is not to seek conversion of non-Muslim to Islam and calling them to the truth, but only to achieve mutual understanding and respect of each other's faith. ${ }^{28}$ This paper argues that such a view is misplaced and incorrect. Granted that non-Muslim's conversion to Islam is a da 'wah's objective, however, it is not the only and ultimate objective in all circumstances. Included in da 'wah's objective is to make nonMuslims understand true Islam so they will not harbour negative attitudes such as hate, hostility and animosity towards Islam and Muslims, while they chose to remain with their original faith.

A deep look at Islamic teachings highlights that Islam does not seek to turn all of Mankind into Muslims, although it claims to be the religion for all, because this would contradict many verses of the Qur'an such as 5:48, 10:99, 11:118-9, 16:93 and 42:8. In these verses, God proclaims that He does not will Man to be "one single ummah (community of believers who uphold obedience to Him only)" like Angels and planets. Instead, Man is given free-will and, with such freedom, Man would eventually choose different life paths. Some would conform to divine guidance and others would astray from it. This is the view held by tafsir scholars when commenting on the verses. ${ }^{29}$

\footnotetext{
${ }^{23}$ See Ibn 'Ashur, Al-Tahrir Wa Al-Tanwir, in 49:13; Sayyid Qutb (n.d.), In the Shade of the Qur'an, in 49:13, retrieved 16 ${ }^{\text {th }}$ June 2020, https://tafsirzilal.wordpress.com/; Wahbah Al-Zuhaili (1991), Al-Tafsir Al-Munir, Damascus: Dar Al-Fikr, Vol. 26, pp. $265-266$.

${ }_{24}$ Ahmet Kurucan and Mustafa Kasim Erol (2012), Dialogue in Islam, p. 12, 18; Al-Majlis Al-Urubbiy Li Al-Ifta' Wa Al-Buhuth (2017), Hukm Al-Hiwar Bayn $\quad$ Al-Adyan, $\quad$ retrieved $\quad 19^{\text {th }} \quad$ September https://www.e-cfr.org/fatwa/\%D8\%AD\%D9\%83\%D9\%85-\%D8\%A7\%D9\%84\%D8\%AD\%D9\%88\%D8\%A7\%D8\%B1-

\%D8\%A8\%D9\%8A\%D9\%86-\%D8\%A7\%D9\%84\%D8\%A3\%D8\%AF\%D9\%8A\%D8\%A7\%D9\%86/; Aljazeera (2004), Hiwar Al-Adyan, 1 June, $\quad$ retrieved $\quad 9^{\text {th }} \quad$ September $\quad 2019, \quad$ https://www.aljazeera.net/programs/oppositedirection/2004/10/3/\%D8\%AD\%D9\%88\%D8\%A7\%D8\%B1-\%D8\%A7\%D9\%84\%D8\%A3\%D8\%AF\%D9\%8A\%D8\%A7\%D9\%86.

${ }^{25}$ Ibn Qayyim Al-Jawziyah (1998), Zad Al-Ma 'ad Fi Hady Khayr Al- Ibad, Beirut: Muassasat Al-Risalah, Vol. 3, pp. 549-563.

${ }^{26}$ Safiur-Rahman Al-Mubarakfuri (1996), The Sealed Nectar: Biography of the Noble Prophet, Riyadh: Maktaba Dar-us-Salam, p. 61.

${ }^{27}$ Al-Qaradawi (2001), Fi Fiqh Al-Aqalliyat Al-Muslimah, pp. 68-71.

28 See Religion Communicators Council (n.d.), Guidelines for Interfaith Dialogue, retrieved $19^{\text {th }}$ September 2019 , https://www.religioncommunicators.org/guidelines-for-interfaith-dialogue; Ahmet Kurucan and Mustafa Kasim Erol (2012), Dialogue in Islam, p. 20; Hasan Hakkar Al-Athari Al-Jazairi (2013), Hukm Hiwar Bayn Al-Adyan Li Al-Shaykh Al-'Allamah Salih bin Muhammad AlLuhaidan, retrieved $27^{\text {th }}$ July 2020, https:/www.youtube.com/watch?v=jpM2IlVbZxk.

${ }^{29}$ Al-Tabari, Jami 'Al-Bayan Fi Tafsir Al-Qur'an, in 10:99, 11:118, 16:93 and 42:8; Al-Qurtubi, Al-Jami Li Ahkam Al-Qur'an, in 11:118, 16:93 and 42:8; Ibn Kathir, Tafsir Al-Our'an Al- 'Azim, in 10:99, 11:118, 16:93 and 42:8; Al-Baidhawi, Anwar Al-Tanzil wa Asrar Al-Ta 'wil, in 5:48, 10:99, 11:118, 16:93 and 42:8; Al-Shawkani, Fath Al-Qadir, in 11:118, 16:93 and 42:8; Al-Alusi, Ruh Al-Ma`ani, in 11:118, 16:93 and 42:8; Ibn 'Ashur, Al-Tahrir Wa Al-Tanwir, in 54:8 and 42:8; Al-Sha rawi, Khawatir, in 16:93 and 42:8; Tantawi, Al-Wasit Fi Tafsir AlQur'an, in 10:99, 11:118, 16:93 and 42:8.
} 
Any non-Muslims who prefer to remain with their original faith but remain friendly to Islam and Muslims, or at least neutral, is better than those who harbour hate and hostility. Some would even go to the extent of helping and supporting Islam and Muslims. These figures could be found in the history of Prophet Muhammad in the examples of, The Prophet's uncle, Abu Talib, who protected him from the persecution of Meccan people but chose not to embrace Islam despite persuasion while he was in his deathbed; ${ }^{30}$ Negus, a Christian king of Abyssinia, who sheltered early Muslims when they migrated to his kingdom seeking protection from the Meccan's persecution, despite the official request of repatriation from Meccan delegates; ${ }^{31}$ Abdullah bin Uraiqit, an Arab pagan, who agreed to be the Prophet's desert guide and was responsible in delivering him safely to Medina from Mecca during hijrah (migration); ${ }^{32}$ and Al-Mut 'im bin 'Adiy, a noble Meccan Arab, who chose to offer protection to the Prophet and allow him to re-enter Mecca after his unsuccessful da wah tour to city of Taif. ${ }^{33}$ These individuals did not exist only during the Prophet's time. It is in the interest of $d a$ 'wah that they be identified, approached and won over; as evidenced across the span of Islamic history.

For this and many other reasons, inter-faith dialogue that does not seek to convert non-Muslim subjects to Islam, has an important role and could contribute positively to the overall interest of $d a$ ' $w$ ah by creating as many supportive figures among other faiths towards the Muslim community. This would mean that Muslims who prefer $d a$ 'wah to convert non-Muslims to Islam could do it via other $d a$ 'wah platforms and approaches without condemning inter-faith dialogue platforms. While those who chose involvement in inter-faith dialogue should honour the accepted rule of the field, without feeling guilty of compromising any Islamic principles. ${ }^{34}$

On the third issue, even if it is proven that there are participants involved in inter-faith dialogue with malicious intent; it is incorrect to claim that the whole inter-faith dialogue is founded on ill intentions or to generalise that all non-Muslims in inter-faith dialogues harbour such intentions. Such views towards non-Muslims are prejudicial and, thus, it is forbidden in Islam. ${ }^{35}$ More importantly, the generalised view is not in harmony with verses of the Qur'an in 2:62, 3:113-4, 60:8-9.

All these verses reject the idea that non-Muslims are a monolithic hostile group. In fact, the verse 3:134 clearly states that "they are not all alike" and highlights some of them are righteous individuals. Their commitment to righteousness and truth makes them potential Muslims, as exemplified by companions such as Salman Al-Farisi and As'amah Al-Najasyi who were Christians and Abdullah bin Salam who was a Jew. ${ }^{36}$ Some scholars of tafsir such as Al-Baidhawi, Al-Alusi, Ibn 'Ashur and Tantawi took the same view when commenting on the verse, "Among them [People of the Book] are believers, but most of them are defiantly disobedient" (The Qur'an, 3:110). ${ }^{37}$ Al-Tabari too held the same understanding of $3: 110$. He used the verse (and its meaning) to explain the meaning of "they are not all alike" in $3: 113 .^{38}$ According to Al-Tabari, the existence of non-hostile non-Muslims could also be found in 60:8, where the Qur'an declares that, "God does not forbid you to show them kindness and to behave towards them with full equity." (The Qur'an, 60:8)

The view that not all people of the book are unrighteous and religiously immoral and some are the opposite is attributed to Al-Akhfash and Al-Farra' too. ${ }^{40}$ Many others tafsir scholars view that verses 2:60 and 3:113-4 were actually revealed on those who converted to Islam from Christianity and Judaism such as Al-Najasyi and Abdullah bin Salam respectively. They were praised for their righteousness after conversion. Thus, the verses did testify for the presence of righteous followers of the Bible or Torah. However, even if it is assumed that this view about the verses is correct, this does not necessarily mean that the Qur'an regards all non-Muslims as hostile to Islam and commands Muslims to treat them with hatred and animosity. This does not conform with the meaning of 60:8 and reports in the history of the

\footnotetext{
${ }^{30}$ Al-Mubarakfuri (1996), The Sealed Nectar, p. 102, 123-124.

${ }^{31}$ Al-Mubarakfuri (1996), The Sealed Nectar, p. 99-104.

${ }^{32}$ Al-Mubarakfuri (1996), The Sealed Nectar, p. 171.

${ }^{33}$ Al-Mubarakfuri (1996), The Sealed Nectar, p. 140.

${ }^{34}$ Ahmet Kurucan and Mustafa Kasim Erol (2012), Dialogue in Islam, pp. 21-22, 26-27.

${ }^{35}$ Ahmet Kurucan and Mustafa Kasim Erol (2012), Dialogue in Islam, pp. 38-69

${ }^{36}$ Al-Shawkani, Fath Al-Qadir, in 3:113-4.

${ }^{37}$ Al-Baidhawi, Anwar Al-Tanzil Wa Asrar Al-Ta'wil, in 3:110; Al-Alusi, Ruh Al-Ma 'ani, in 3:110; Ibn 'Ashur, Al-Tahrir Wa Al-Tanwir, in

3:110; Tantawi, Al-Wasit Fi Al-Qur'an Al-Karim, in 3:110

${ }^{38}$ Al-Tabari, Jami Al-Bayan Fi Tafsir Al-Qur'an, in 3:113.

${ }^{39}$ Al-Tabari, Jami 'Al-Bayan Fi Tafsir Al-Qur'an, in 60:8.

${ }^{40}$ Al-Qurtubi, Al-Jami 'Li Ahkam Al-Qur'an, in 3:113-4; Al-Shawkani, Fath Al-Qadir, in 3:113-4.
} 
Prophet of good non-Muslims. Some of them became Muslims such as Salman Al-Farisi, Abdullah bin Salam and Al-Najasyi and some were not such as Abu Talib and Mut 'im bin `Adiy.

In today's context, not all non-Muslims who are involved in inter-faith dialogue and recognised its importance for peaceful-coexistence do it for the idea that all religions are equally valid and seek to promote it. Roland Chia, a professor at Trinity Theological College (Singapore), after stressing on the importance of Christians' participation and engagement in inter-faith dialogue, writes that "dialogue cannot be conducted on the basis of the religious and epistemological relativism" or "demands that participants regard the truth-claims of their respective religions as tentative, inconclusive, and therefore in principle open to radical revision." ${ }^{41}$

Similar view was expressed by The Chin Liew, Emeritus Professor at National University of Singapore. $\mathrm{He}$ asserts that the idea that all religions are equally true is not necessarily a right starting point for promoting harmonious living among religionists because it is neither realistic nor necessary. ${ }^{42} \mathrm{He}$ then argues:

So we must take as our starting point the existence of genuine, and sometimes conflicting and incompatible, beliefs about religious matters, such as the meaning of life, the origin of the universe, the existence of God, the after-life, reincarnation and ideas of the sacred. Under what conditions, and on what basis, should people with such differences live together harmoniously and cooperate with one another? The first step is to establish proper grounds for religious toleration. Of course a flourishing community would need to have more active forms of engagement among its different members than is required by mutual toleration. But unless they can at least tolerate one another, they would not even constitute or survive as a community. ${ }^{43}$

More importantly, the theological legitimacy of the field of inter-faith dialogue first and foremost must be established on scriptural evidences (the Qur'an and hadith) that permit it and these evidences exist as outlined in the above sub-section. The presence of ill-intentioned participants in the field of interfaith dialogues, even if proven true, could only, at best, necessitates prudence and caution from Muslims, not a prohibition from it. ${ }^{44}$

On balance, we can recognise that inter-faith dialogue does have its pros and cons for the participants. In such situations, one should not only think about avoiding it in order to protect for potential harms but also weighing in the potential benefits that could be gained. If Muslims hypothetically think interfaith dialogues does not favour their interests, they could always organise their own inter-faith dialogue and initiatives to their favour and advantages, instead of a total avoidance. Also, the right approach is to enjoin critical thinking and proper training for Muslims' involvement in order to protect them from compromising their faiths; instead of ruling it as prohibition.

All the above could be seen by Maulana Siddique's example. He founded JAMIYAH (originally known as Jam ¿yah Al-Da`wah Al-Islamiyah or All-Malaya Islamic Missionary Society) in 1932 to train da wah activists. ${ }^{45}$ It is very possible to think that some were trained for the purpose of inter-faith dialogue via IRO which he himself founded.

\section{Jordanian Project - A Common Word}

A more practical response to the detractors and an affirmation to the legitimacy of inter-faith dialogue in Islam can be exemplified in a grand project known as A Common Word sponsored by Jordanian Government with the support of Muslim scholars, thinkers and leaders. The project was launched in September 2007. Its main objective is to promote mutual understanding and peaceful relations between followers of Islam, Christianity and Judaism based on the common teachings of the three faiths. ${ }^{46}$ When

\footnotetext{
${ }^{41}$ Roland Chia (2019), “Clarifying Inter-faith Dialogue,” Pulse, retrieved $28^{\text {th }}$ July 2020, https://ethosinstitute.sg/interfaith-dialogue/.

${ }^{42}$ Ten Chin Liew (2008), "Religious Diversity, Toleration and Interaction," in Lai Ah Heng (ed.), Religious Diversity in Singapore, Singapore: Iseas, pp. 558-559

${ }^{43}$ Liew (2008), "Religious Diversity," pp. 559-560.

${ }^{44}$ Ahmet Kurucan and Mustafa Kasim Erol (2012), Dialogue in Islam, p. 25

${ }^{45}$ JAMIYAH (n.d.), About/History, retrieved $19^{\text {th }}$ September 2019, https://www.jamiyah.org.sg/abouthistory/.

${ }^{46}$ A Common Word (n.d.), Introduction to A Common Word Between Us and You, retrieved 19th September 2019, www.acommonword.com.
} 
launched in Amman, the project proclaimed a declaration titled as A Common Word Between Us and You signed, as evidence of support and endorsement, by more than 400 Muslims including prominent contemporary scholars of Islam from all over the world. ${ }^{47}$

Muslims in Singapore who detract from any inter-faith dialogues should then ask themselves the following; Are these scholars ignorant when signing the initiative's declaration if inter-faith dialogue is indeed prohibited in Islam?; Would they endorse the declaration if the call for inter-faith dialogue is forbidden in Islam?; Are they foolish to collectively be deceived to enter into the inter-faith dialogue field?; Would hundreds of scholars from different orientations of Islam come to an agreement if the initiative is definitively forbidden in Islam? In Singapore's context, the importance and necessity of Muslims' participation in inter-faith could be supported by two other factors in addition to the above; a) the preservation and continuation of Muslim historical legacy and tradition, and b) Singapore's social context where Muslims as minority live in.

\section{Preservation and Continuation of a Tradition}

Unlike Muslim minorities in other countries, inter-faith dialogue is an important part of Singapore's da 'wah's tradition and history. It began decades before Singapore's independence and was pioneered by a Muslim scholar. It was Maulana Abdul Aleem Siddique's strong conviction to use inter-faith dialogue as a bridge towards understanding among people of different faiths. Maulana Siddique believed in dialogue as a basis for peaceful co-existence is legitimate in Islam. He was a respected local Muslim scholar, who was active in teaching Islam among Muslims; as well as sharing Islam with nonMuslims in Singapore. ${ }^{48}$

Maulana Siddique left behind two important legacies in Singapore which contributed significantly in building trust, and laying the foundations for inter-faith dialogues. Firstly, he established JAMIYAH. ${ }^{49}$ This organisation is mandated to teach Islam among Muslims. Secondly, he founded the Inter-Religious Organisation (IRO) in 1949 - where currently ten representatives of major faiths in Singapore come together and organise activities where understanding of different faiths could be shared and promoted for the purpose of harmonious co-existence in Singapore. ${ }^{50}$ Both JAMIYAH and IRO are still active today.

By founding the two organisations, Maulana Siddique left behind a distinctly Muslim Singaporean legacy and tradition that links Islam with inter-faith dialogue and entrenched $d a$ ' wah with a non-violent and tolerant mindset. He showed that da wah meant seeking to share about Islam to others without necessarily the need for conversion. ${ }^{51}$ Maulana Siddique's legacy and tradition must be duly recognised as a uniquely Singaporean Muslim tradition and must be preserved by current and future generations. In this regard, Singapore Muslims' active participation and involvement in inter-faith dialogue is not a recent phenomenon. Neither was it a mere reaction or conformance to contemporary needs and modern (Western) trends. More accurately, involvement in this arena is a factual continuation of a tradition founded by respected local Muslim scholar.

PERGAS (Singapore Islamic Scholars and Religious Teachers Association) highlighted Maulana Siqqidue's biography in their book project titled 'Beacons of the Ummah: Tracing the Footsteps of Singapore's Islamic Religious Leader'. The book compiles a list of Singapore's Muslim scholars since the $19^{\text {th }}$ century with the objective of, among others, inspiring positive contributions from Singaporean Muslims. Maulana Siddique is honored in the book as a great figure that had dedicated to $r$ serving the entire humanity. Not only has he benefitted thousands of people of various races and from various countries in Asia, Europe and America with his knowledge and wisdom, Maulana Siddique had also left behind many legacies in the form of missionary organisations, mosques, orphanages and hospitals

\footnotetext{
47 A Common Word (n.d.), Signatories: A Common Word Between Us \& You, retrieved 19 $9^{\text {th }}$ September 2019, https://www.acommonword.com/signatories/.

48 JAMIYAH (n.d.), About/History.

49 JAMIYAH (n.d.), About/History.

${ }^{50}$ PERGAS (2014), Beacons of the Ummah: Tracing the Footsteps of Singapore's Islamic Religious Leaders, Singapore: PERGAS, pp. 4144; Inter-Religious Organisation (n.d.), A Brief History Of The Inter-Religious Organisation, Singapore (IRO), retrieved 19th September 2019, https://iro.sg/history/; Vina Jie-Min Prasad and Jaime Koh (2014), "Inter-Religious Organisation, Singapore," SingaporeInfopedia, retrieved $19^{\text {th }}$ September 2019, http://eresources.nlb.gov.sg/infopedia/articles/SIP_2014-12-09_125938.html.

51 Masjid Abdul Aleem Siddique (n.d.), Maulana Abdul Aleem Siddique, retrieved 19 $9^{\text {th }}$ September 2019, http://www.aleemsiddique.org.sg/index.php?/Info/maulana-abdul-aleem-siddique.html.
} 
in many countries. ${ }^{52}$ Furthermore, a new specialist institution was established in October 2016 to represent a continuation of Maulana Siddique's legacy, and create a new platform for inter-faith dialogue for Muslims in addition to the IRO, various national grassroot organisations and others. The institution is known as The Harmony Centre. Based at An-Nahdhah Mosque, the centre is under the purview of MUIS to promote religious harmony through inter-faith dialogue. ${ }^{53}$ The Harmony Centre is a safe and suitable venue for Muslims who are new to the norms of inter-faith dialogue to engage in an open and safe space. The centre has so far proven to be a good platform to promote inter-faith awareness and activism among Muslims and by Muslims for the common good of the larger community.

The continuation of current good work done by the centre and other Muslims' involvement in interfaith dialogue via other platforms, however, cannot be taken for granted. Continuous efforts to promote right understanding of Islam vis-à-vis inter-faith dialogue work and awareness of its historical legacy must be made.

\section{A Social Necessity for Minority Muslims in a Multi-Cultural Society}

First, it must be made clear the religious legitimacy of Singaporean Muslims to live as minority in a secular state of Singapore has inevitably constrained their ability to practice Islam. This is important in view of the continuing threat from extremist ideology by groups like IS and Al-Qaeda that denounces Muslims living in non-Muslim countries and propagates hijrah to lands ruled by them. The legitimacy of Singapore Muslims leadership is led by two important Islamic organisations in Singapore; a) PERGAS, an NGO and the umbrella body of ulama (Muslim scholars) in Singapore, and b) the Islamic Religious Council of Singapore (MUIS), a government statutory board overseeing Muslim affairs in Singapore.

After expounding on past ulama's discourse on hijrah in Islam in its book Moderation in Islam in the Context of Singapore Muslim Community in Singapore, PERGAS concludes that living and staying put in Singapore for Muslims is encouraged in Islam, not hijrah (migration) on the fact that freedom to practice Islam and protection of Muslim other civil rights are good and there is interest of Islam in the continuation of Muslims' presence in the country. ${ }^{54}$ To strengthen the position further, PERGAS holds that the principle basis of Muslim and non-Muslim relations is peace and harmony, not war or armed jihad. Thus, Muslims are commanded to interact and relate with non-Muslims on positive grounds such as dialogue for mutual understanding and cooperation for common good. ${ }^{55}$

As for MUIS, it asserts clearly, that there should not be any conflict between being a good Muslim and a good citizen. A good Singaporean Muslim should also be a good law-abiding citizen and true to the Singapore pledge in upholding justice and harmony, respect for religious freedom and preserve social harmony. ${ }^{56}$

In a multi-cultural, multi-religious society like Singapore, Muslims naturally and inevitably have daily interactions with communities of different faiths and ethnicities. It is neither tenable nor theologically correct for Muslims in Singapore to lead an exclusivist lifestyle, championing only for the rights of their own community. Interacting and cooperating with others based on humanity and common interests is the only option. In fact, the inevitability and the effect of such interaction is greater today and in the future due to the prevalent use and advancement of information and communication technology where exposure to diverse faiths, cultures and ethnicities outside Singapore is multiplied significantly.

However, this interaction and exposure could bring both positive and negative effects. From a positive view, it could potentially enrich the resources and opportunities for growth and development, at personal and community level. However, on the flipside, it could be a source of conflict and tension between communities and people of different faiths. Thus, diversity and differences must be properly managed in order for the Muslim community to gain the benefits and to avoid the harms. One way to do this is to develop greater understanding between different communities.

\footnotetext{
${ }^{52}$ Siddique (n.d.), Maulana Abdul Aleem Siddique, p. 43.

${ }^{53}$ Harmony Centre (n.d.), About, retrieved $19^{\text {th }}$ September 2019, https://www.facebook.com/pg/Harmony.Centre/about/?ref=page internal.

${ }^{54}$ PERGAS (2004), Moderation in Islam in the Context of Singapore Muslim Community in Singapore, Singapore: PERGAS, pp. $224-236$.

${ }^{55}$ PERGAS (2004), Moderation in Islam, pp. 187-211.

${ }^{56}$ MUIS (2006), Risalah for Building a Singapore Muslim Community of Excellence, Singapore: MUIS, p. 83
} 
Although diversity is natural, harmonious living among diverse communities does not come naturally in Man. There remain pockets communities who prefer living in isolation, devoid of any interaction with people from other walks of life, faiths, or ethnicity. They choose not to embrace diversity around them. These individuals manifest ideas that promote hate towards "the different others". They strive to cultivate and compel people to hold similar viewpoints and behaviours. This is further emboldened by the proliferation of information and communication technology. Some would resort to violence to achieve this using religious, cultural, national or ideological pretext such as Islamophobia movement, ideology of IS/Al-Qaeda and anti-immigrant tendency.

Efforts to promote and cultivate understanding among people of different faiths through dialogue and social interaction becomes critical and important, not optional, especially in Singapore context where nation-building is work-in-progress and multiple bloody racial riots had taken place. ${ }^{57}$ This standpoint is also validated by prominent scholars such as Al-Qaradawi and Sheikh Abdullah Bin Bayyah in their books that seek to guide Muslim minorities living in non-Muslim countries all over the world. ${ }^{58}$ Fethullah Gulen, an influential contemporary Turkish Muslim thinker, believes that "inter-faith dialogue is a must today. ${ }^{" 59}$ Fortunately, the fulfilment of this social necessity is made more conducive by the Singapore government keen interest on the matter too. In Singapore, the government is always guarding and actively promoting social harmony among various ethnic groups due to the traumatic experiences of racial riots that occurred before and after the country's independence.

Inter-faith dialogue among various faith communities was given greater emphasis and support after the discovery of Jemaah Islamiyah's plot and the arrest of its members at the end of 2001. The religious character of the JI threat along with the Malay-Muslim background of arrested JI members put Islam and Malay/Muslim community under intense scrutiny from fellow non-Muslims and non-Malay Singaporeans. This pushed to the forefront pressure points and risks within Singapore's social fabric and social harmony.

Cognizant of this, the Singapore government launched Inter-Racial and Religious Confidence Circle (IRCC) - a grassroots level grouping of individuals from different faiths, at each constituency with the objective of confidence building and understanding. The circles were then networked at national level under the purview of Ministry of Culture, Community and Youth. ${ }^{60}$ The most recent major initiative is the International Conference on Cohesive Societies in June 2019 which ended with a declaration of Commitment to Safeguard Religious Harmony signed by religious and community leaders. The declaration is a statement of commitment by senior religious leaders for unity in promoting the common good, against division and discord between religious communities and to regard differences not as separation, but as contribution - diverse gifts brought to the future that all Singaporeans share. ${ }^{61}$

The government's active involvement has fostered a vibrant and positive environment at the national level for inter-faith dialogue. Their consistent support in this area has given a safe space for existing inter-faith dialogues to flourish. The tireless efforts in building trust and awareness, the provision of institutional and financial support has been tremendous. With such support, the long-term sustainability and prospect for the inter-faith work is very positive.

However, there is also a negative view towards government's active involvement in the inter-faith dialogue field. It makes the arena as another means for the government to shape the society which includes Muslim community in accordance to its political interest which is the continuation and preservation of the incumbent power. Instead of being empowered by social activism, activists and societies of the field become government's extended hand. In the eyes of many others, they are regarded

\footnotetext{
57 National Library Board (2014), “Communal Riots of 1964," SingaporeInfopedia, retrieved 19 ${ }^{\text {th }}$ September 2019, http://eresources.nlb.gov.sg/infopedia/articles/SIP_45_2005-01-06.html; HistorySg (2012), Communal Riots Occur - 21 $1^{\text {st }}$ July 1964, retrieved 19th September 2019, http://eresources.nlb.gov.sg/history/events/979a03fa-6b1d-4562-8c74-bb8157e9c2b1; Loh Chee Kong (2017), "52 years of multiracialism - where does S'pore go from here?" Today, retrieved 19 ${ }^{\text {th }}$ September 2019, https://www.todayonline.com/singapore/52-years-multiracialism-where-does-spore-go-here; National Library Board (2014), "Maria Hertogh Riots", SingaporeInfopedia, retrieved 19th September 2019, http://eresources.nlb.gov.sg/infopedia/articles/SIP_83_2005-02-02.html.

${ }^{58}$ See `Abd Allah bin Bayyah (2007), Sina ‘at Al-Fatwa Wa Fiqh Al-Aqalliyyat, Jeddah: Dar Al-Minhaj, pp. $16 \overline{7}-1 \overline{7} 3$.

59 See Fethullah Gulen (2004), The Necessity of Interfaith Dialogue: A Muslim Perspective, New Jersey: The Light, available at https:/fgulen.com/en/fethullah-gulens-works/thought/recent-articles/24901-the-necessity-of-interfaith-dialogue.

60 IRCC (n.d.), Overview: About Inter-racial and Religious Confidence Circle, retrieved $21^{\text {st }}$ September 2019 , https://www.ircc.sg/ABOUT\%20IRCC; Mathew Mathews and Wong Fai Ching (eds.) (2016), Managing Diversity in Singapore: Policies and Prospects, Singapore: IPS and World Scientific, available at https://www.worldscientific.com/page/p1083.

${ }^{61}$ IRCC (n.d.), Commitment to Safeguard Religious Harmony, retrieved 21 ${ }^{\text {st }}$ September 2019, https://www.ircc.sg/commitment.
} 
as "coopted people" whom the society could not rely upon to voice out their religious, social and political concerns.

This view is not totally invalid. It was expressed by some activists interviewed mentioned before in this paper. Nevertheless, few responses could be made here. Firstly, the Singapore government's active involvement in the field for whatever agenda it seeks to achieve has no effect in the permissibility and theological importance of inter-faith dialogue in Islam. This is because the primary basis of any Islamic ruling is the scriptural imperatives and the scriptures' call upon Muslims to effect dialogue with nonMuslims are very clear. Also, the Prophet engaged in inter-faith dialogue knowingly that non-Muslims would have agenda and interest of their own and may not be compatible with Muslims' interest. Secondly, it is wrong to view the government's involvement in the field from the risk viewpoint only. One could also see overlapping and common goods in it that Muslims' contribution is enjoined in the Qur'an (5:2). Thirdly, it would be better for Muslims in addressing these concerns of the government's agendas with prudence, caution and critical thinking, instead of avoidance and disengagement from the field. This not only in line with the first and second points, it also reflects maturity and confidence. Finally, to assume that involvement in inter-faith dialogue would necessarily lead to being coopted by the government and to have such generalised views towards all initiatives and people in the field is a prejudice and biased perspective that does not befit the teachings of Islam.

\section{Conclusion}

Some contemporary Muslims regard inter-faith dialogue as theologically apprehensible because it will lead to compromise of key tenets of Islam. Although the view is held by minority of Muslims, the risk of it should not be underestimated in the context of minority Muslims living in Singapore. The threat of Al-Qaeda/IS ideology had influenced several Muslim Singaporeans since the discovery of Jemaah Islamiyah cells in 2001/2002 and the arrest of self-radicalised individuals as recent as February 2020 which involved a 17-year-old teenager.

However, not all Muslims who are apprehensive towards inter-dialogue are ideologically inclined towards violent groups like Al-Qaeda and IS. Some of them belongs to the conservative fringe and are equally apprehensive towards Al-Qeda/IS violent ideology. However, this would also mean that this segment of Muslims is bigger than the violent radicals and, consequently, the risk this line of thinking poses to harmonious co-existence between Muslims and non-Muslims in Singapore is greater.

On this note, efforts to clarify and promote Islam's positive stand towards inter-faith dialogue must be continuously made in order to guide and reinforce the right understanding of Islam and inoculate against any apprehension towards an open dialogue. By highlighting relevant verses in the Qur'an, tafsir scholars's discussion of them and the sirah (history) of the Prophet, this paper has shown that interfaith dialogue is not only permissible, but also encouraged.

This paper goes further to argue for the necessity and importance of Singapore Muslims' participation in inter-faith dialogue in view of the multicultural society they live in. As minorities, active constructive engagement with non-Muslim is critical even if it is not meant for converting others to Islam because it would help to promote correct and positive image of Muslims and curbing the rise of Islamophobia. Both are considered as critical maslahah (interest) that Muslims must strive to attain.

However, Muslims' participation in inter-faith dialogue becomes more important in Singapore context in view of the fact that the initiative was pioneered by respected Muslim scholars, Maulana Abdul Aleem Siddique, who founded the IRO. Muslim community carries the responsibility to preserve this legacy and tradition which is best achieved by following his footstep and actively contributing to the advancement of inter-faith dialogue.

There is concern that participation in inter-faith works would lead to the community being dragged into government political agenda which may not necessarily in line with the community's interests. While the paper recognises the validity of the concern, it counter-argues that such concern does not invalidate the theological position of inter-faith dialogue in Islam. The paper further argues that the concern is also biased towards the risks and negative effects only, sidestepping various important maslahah of inter-faith works for Muslim community in Singapore. 
The Necessity and Importance of Theological Engagement with Non-Muslims for Singapore Muslim Community

\section{References}

Al-Qur'an commentaries (tafsir) online library, retrieved $17^{\text {th }}$ July 2020 , https://www.altafsir.com/Tafasir.asp?tMadhNo $=0 \& \mathrm{tTafsirNo}=0 \& \mathrm{tSoraNo}=1 \& \mathrm{tAyahNo}=1 \& \mathrm{tDisplay}$ $=$ no\& Language $\mathrm{ID}=1$.

A Common Word (n.d.), Signatories: A Common Word Between Us \& You, retrieved 19th September 2019, https://www.acommonword.com/signatories/.

Abas, Suha (2019), Mafhum Hiwar Al-Adyan, retrieved $19^{\text {th }}$ September 2019, https://hyatoky.com/\%D9\%85\%D9\%81\%D9\%87\%D9\%88\%D9\%85_\%D8\%AD\%D9\%88\%D8\%A7 \%D8\%B1_\%D8\%A7\%D9\%84\%D8\%A7\%D8\%AF\%D9\%8A\%D8\%A7\%D9\%86.

'Abd Allah, Muhammad Husain (2016), "Mawqif Al-Islam Min Al-Hiwar Bayn Al-Adyan," Majallat Al-Wa $i y$, retrieved $19^{\text {th }}$ September 2019, https://www.al-waie.org/archives/article/3700.

Ali, Mohamed (2015), Roots of Religious Extremism: The Understanding the Salafi Doctrine of AlWala' Wal Bara', London: Imperial College Press.

Aljazeera (2004), Hiwar Al-Adyan, retrieved $19^{\text {th }}$ September 2019 , https://www.aljazeera.net/programs/oppositedirection/2004/10/3/\%D8\%AD\%D9\%88\%D8\%A7\%D8 \%B1-\%D8\%A7\%D9\%84\%D8\%A3\%D8\%AF\%D9\%8A\%D8\%A7\%D9\%86.

Al-Barrak, 'Abd Al-Rahman Nasir (n.d.), Al-Da wah Ila Wahdah Al-Adyan Min Nawaqid Al-Islam, retrieved $19^{\text {th }}$ September 2019, https://www.saaid.net/fatwa/f64.htm.

Al-Islam Su'al Wa Jawab (2000), Hukm Al-Da wah Ila Taqarub Al-Adyan, retrieved $19^{\text {th }}$ September 2019 , https://islamqa.info/ar/answers/10232/\%D8\%AD\%D9\%83\%D9\%85\%D8\%A7\%D9\%84\%D8\%AF\%D8\%B9\%D9\%88\%D8\%A9-\%D8\%A7\%D9\%84\%D9\%89-

$\% \mathrm{D} 8 \% \mathrm{AA} \% \mathrm{D} 9 \% 82 \% \mathrm{D} 8 \% \mathrm{~A} 7 \% \mathrm{D} 8 \% \mathrm{~B} 1 \% \mathrm{D} 8 \% \mathrm{~A} 8-$

\%D8\%A7\%D9\%84\%D8\%A7\%D8\%AF\%D9\%8A\%D8\%A7\%D9\%86.

Al-Jawziyah, Ibn Qayyim (1998), Zad Al-Ma`ad Fi Hadyi Khayr Al-'Ibad, Beirut: Muassasat AlRisalah, Vol. 3.

Al-Jazairi, Hasan Hakkar Al-Athari (2013), Hukm Hiwar Bayn Al-Adyan Li Al-Shaykh Al- 'Allamah Salih bin Muhammad Al-Luhaidan, retrieved $27^{\text {th }}$ July 2020, https://www.youtube.com/watch?v=jpM2IlVbZxk.

Al-Kitab Wa Al-Sunnah Bi Fahm Salf Al-Ummah (2015), Hukm Hiwar Bayn Al-Adyan (Salih AlFawzan), retrieved $27^{\text {th }}$ July 2020, https://www.youtube.com/watch?v=vMCRdnB491Y.

Al-Majlis Al-Urubbiy Li Al-Ifta' Wa Al-Buhuth (2017), Hukm Al-Hiwar Bayn Al-Adyan, retrieved $19^{\text {th }}$ September $\quad 2019, \quad$ https://www.e-cfr.org/fatwa/\%D8\%AD\%D9\%83\%D9\%85\%D8\%A7\%D9\%84\%D8\%AD\%D9\%88\%D8\%A7\%D8\%B1-\%D8\%A8\%D9\%8A\%D9\%86-

\%D8\%A7\%D9\%84\%D8\%A3\%D8\%AF\%D9\%8A\%D8\%A7\%D9\%86/.

Al-Mubarakfuri, Safiur-Rahman (1996), The Sealed Nectar: Biography of the Noble Prophet, Riyadh: Maktaba Dar-us-Salam.

Al-Silmi, `Abd Al-Rahim Samayil (n.d.), Al-Hiwar Bayn Al-Adyan: Haqiqatuh Wa Anwa uh, N.pl.: N.p..

Al-Qaradawi, Yusuf (2001), Fi Fiqh Al-Aqalliyat Al-Muslimah, Qahirah: Dal Al-Shuruq.

AshashaS (2016), Al-Shaykh Ibn 'Uthaimin Yuljim Du'at Tawhid Al-Adyan, 27 ${ }^{\text {th }}$ July 2020, https://www.youtube.com/watch?v=jMoYf97UwMs. 
bin Bayyah, `Abd Allah (2007), Sina `at Al-Fatwa Wa Fiqh Al-Aqalliyyat, Jeddah: Dar Al-Minhaj.

Bisyarah, Jawad (2002), "Haqiqat Al-Hiwar Bayn Al-Adyan," Al-Hiwar Al-Mutamaddin, retrieved $19^{\text {th }}$ September 2019, http://www.ahewar.org/debat/show.art.asp?aid=2784\&r=0.

Chia, Roland (2019), "Clarifying Inter-faith Dialogue," Pulse, retrieved $28^{\text {th }}$ July 2020, https://ethosinstitute.sg/interfaith-dialogue/.

Dabiq. No. 14 and 15.

Forde, Gerard (2013), Journey Together: A Resource for Christian Muslim Dialogue, Ireland: Cois Tine, available at https://www.dublincityinterfaithforum.org/cmsfiles/resources/a-journeytogether.pdf.

Gulen, Fethullah (2004), The Necessity of Interfaith Dialogue: A Muslim Perspective, New Jersey: The Light, available at https://fgulen.com/en/fethullah-gulens-works/thought/recent-articles/24901-thenecessity-of-interfaith-dialogue.

Harmony Centre (n.d.), About, retrieved 19th September 2019, https://www.facebook.com/pg/Harmony.Centre/about/?ref=page_internal.

Hassan, Muhammad Haniff (2009), "Jihadi Ideology: An Overview," in Arnaud de Bochgrave, Thomas Sanderson and David Gordon (eds.), Conflict, Community and Criminality in Southeast Asia and Australia, Washington: CSIS.

HistorySg (2012), Communal Riots Occur - $21^{\text {st }}$ July 1964, $19^{\text {th }}$ September 2019, http://eresources.nlb.gov.sg/history/events/979a03fa-6b1d-4562-8c74-bb8157e9c2b1.

Ibrahim, Mohammad Sa id Mitwally (2010), "Inter-Faith Dialogue: A Muslim Legal Perspective on Its Validity, Concept and Practices," INSIGHTS: Muslim-Non-Muslim Relations, Vol. 3, No. 1.

IRCC (n.d.), Overview: About Inter-racial and Religious Confidence Circle, retrieved $21^{\text {st }}$ September 2019, https://www.ircc.sg/ABOUT\%20IRCC.

Inter-Religious Organisation (n.d.), A Brief History Of The Inter-Religious Organisation, Singapore (IRO), retrieved $19^{\text {th }}$ September 2019, https://iro.sg/history/.

JAMIYAH (n.d.), About/History, retrieved $19^{\text {th }} \quad$ September 2019 , https://www.jamiyah.org.sg/abouthistory/.

Kurucan, Ahmet and Erol, Mustafa Kasim (2012), Dialogue in Islam: Quran - Sunnah - History, London: Dialogue Society.

Lai Ah Heng (ed.) (2008), Religious Diversity in Singapore, Singapore: ISEAS.

Loh, Chee Kong (2017), "52 years of multiracialism - where does S'pore go from here?," Today, retrieved $19^{\text {th }}$ September 2019, https://www.todayonline.com/singapore/52-years-multiracialismwhere-does-spore-go-here.

Mathews, Mathew and Wong, Fai Ching (eds.) (2016), Managing Diversity in Singapore: Policies and Prospects, Singapore: IPS and World Scientific.

Masjid Abdul Aleem Siddique (n.d.), Maulana Abdul Aleem Siddique, retrieved $19^{\text {th }}$ September 2019, http://www.aleemsiddique.org.sg/index.php?/Info/maulana-abdul-aleem-siddique.html.

Matson, Ingrid (2013), Of Fences and Neighbors, retrieved $19^{\text {th }}$ September 2019, $\mathrm{http}$ ://ingridmattson.org/article/of-fences-and-neighbors/. 
The Necessity and Importance of Theological Engagement with Non-Muslims for Singapore Muslim Community Md. Sanaullah (2014), "Interfaith Dialogue in Islam: A Scriptural Scrutiny," Journal of Humanities and Social Sciences, Vol. 19. No. 3.

Ministry of Home Affairs (2003), White Paper: Jemaah Islamiyah and the Threat of Terrorism, Singapore: Ministry of Home Affairs.

MUIS (2006), Risalah for Building a Singapore Muslim Community of Excellence, Singapore: MUIS.

National Library Board (2014), "Communal Riots of 1964," SingaporeInfopedia, retrieved $19^{\text {th }}$ September 2019, http://eresources.nlb.gov.sg/infopedia/articles/SIP_45_2005-01-06.html.

(2014), "Maria Hertogh Riots," SingaporeInfopedia, retrieved $19^{\text {th }}$ September 2019, http://eresources.nlb.gov.sg/infopedia/articles/SIP_83_2005-02-02.html.

Nur Al-'Ilm (2016), Hukm Al-Hiwar Bayn Al-Adyan (Salih Al-Fawzan), retrieved $19^{\text {th }}$ September 2019, https://www.youtube.com/watch?v=OagCv4EBSQU.

PERGAS (2014), Beacons of the Ummah: Tracing the Footsteps of Singapore's Islamic Religious Leaders, Singapore: PERGAS.

(2004), Moderation in Islam in the Context of Singapore Muslim Community in Singapore, Singapore: PERGAS.

Perkins, Mackenzie (2019), "Singapore: The Most Religiously Diverse Country in the World," Learn Religions, retrieved $19^{\text {th }}$ September 2019, https://www.learnreligions.com/singapore-religion-4766642.

Pew Research Center (2014), Global Religious Diversity, retrieved $19^{\text {th }}$ September 2019 , https://www.pewforum.org/2014/04/04/global-religious-diversity/.

Prasad, Vina Jie-Min and Koh, Jaime (2014), "Inter-Religious Organisation, Singapore," $\begin{array}{llll}\text { SingaporeInfopedia, } & \text { retrieved } & 9^{\text {th }} & \text { September }\end{array}$ http://eresources.nlb.gov.sg/infopedia/articles/SIP_2014-12-09_125938.html.

Qanat Al-Shaykh Khalid Al-Faluji (2019), Rad Al- Allamah Al-Fawzan `Ala Du'at Al-Tasamuh Wa Wahdat Al-Adyan, retrieved $27^{\text {th }}$ July 2020, https:/www.youtube.com/watch?v=nVmcel8yvhI.

Religion Communicators Council (n.d), Guidelines for Interfaith Dialogue, retrieved $19^{\text {th }}$ September 2019, https://www.religioncommunicators.org/guidelines-for-interfaith-dialogue.

Taha, Anis Malik (2010), "Hiwar Al-Adyan Bayn Bina' Jusur Al-Tafahum Wa Hifz Al-Hawiyah (Interreligious Dialogue between Building Bridges of Mutual Understanding and Preservation of Identity)," Al-Tajdid, Vol. 14, No. 27.

Ten, Chin Liew (2008), "Religious Diversity, Toleration and Interaction," in Lai Ah Heng (ed.), Religious Diversity in Singapore, Singapore: Iseas.

Zuhayr, Ghadah (2018), “Ghita' Siyasi Li Mumarasat Al-Bash 'ah!," Aljazeera blog, retrieved $27^{\text {th }}$ July 2020, https://www.aljazeera.net/blogs/2018/9/20/\%D8\%AD\%D9\%88\%D8\%A7\%D8\%B1$\% \mathrm{D} 8 \% \mathrm{~A} 7 \% \mathrm{D} 9 \% 84 \% \mathrm{D} 8 \% \mathrm{A3} \% \mathrm{D} 8 \% \mathrm{AF} \% \mathrm{D} 9 \% 8 \mathrm{~A} \% \mathrm{D} 8 \% \mathrm{A7} \% \mathrm{D} 9 \% 86-$ \%D8\%BA\%D8\%B7\%D8\%A7\%D8\%A1-\%D8\%B3\%D9\%8A\%D8\%A7\%D8\%B3\%D9\%8A$\% \mathrm{D} 9 \% 84 \% \mathrm{D} 9 \% 85 \% \mathrm{D} 9 \% 85 \% \mathrm{D} 8 \% \mathrm{~A} 7 \% \mathrm{D} 8 \% \mathrm{~B} 1 \% \mathrm{D} 8 \% \mathrm{~B} 3 \% \mathrm{D} 8 \% \mathrm{~A} 7 \% \mathrm{D} 8 \% \mathrm{AA}-$ $\% \mathrm{D} 8 \% \mathrm{~A} 8 \% \mathrm{D} 8 \% \mathrm{~B} 4 \% \mathrm{D} 8 \% \mathrm{~B} 9 \% \mathrm{D} 8 \% \mathrm{~A} 9$. 
Journal of Al-Tamaddun, Vol. 15 (2), 2020, 29-43 